\title{
Experimental L2 text production with WinPitch LTL
}

Darya Sandryhaila-Groth

LLF, UFR Linguistique, Paris-Diderot Paris 7, France

https://doi.org/10.36505/ExLing-2016/07/0033/000292

\begin{abstract}
Speech production of adults learning French as a second language in a nonfrancophone environment will be discussed in this paper. The focus is mostly on the prosody of French. Two groups of adult US native speakers used WinPitch Pro and its WinPitch LTL version for teaching and learning a foreign language. Their respective performances have been compared and evaluated.
\end{abstract}

Key words: Second language and prosody teaching, speech visualization.

\section{Introduction}

The oral performance in French as L2 has been ignored for a long time, especially suprasegmental but also their segmental aspects (Guimbretière 1994, 2000; Lauret 2007). Only recently, notable changes have occurred for learners of French, i.e., when authors of teaching methods began to be more interested in phonetics and included several exercises of repetition, discrimination, etc. in their textbooks of French (Abry 2009; Abry and Chalaron 2011; Kamoun and Ripaud 2016).

\section{Methodology}

In this study, two groups of learners of French were analyzed. All of them were American English native speakers and had an intermediate level in French. The first group of participants were university students at UCLA and the second one were adult students at the French language school Alliance française.

In a first step, individual comments were provided to each of the students, after the instructor has been listening to their individual recordings with Audacity software. The students had worked in groups and been listening to each other, and they were all interacting during the learning process. They were able to give their opinion about the quality of the repetition of a student, and his phonetic/prosodic errors. In addition, the instructor was listening and correcting the oral productions as well. To simplify the repetition task, models of the sentences were played to the students at reduced speed $(70 \%)$, with the help of the WinPitch software. At the end of a training period, a final recording of each of the students in both groups was made with WinPitch LTL.

ExLing 2016: Proceedings of $7^{\text {th }}$ Tutorial and Research Workshop on Experimental Linguistics, 27 June - 2 July 2016, Saint Petersburg, Russia 


\section{Hypothesis}

The first hypothesis is that the first group of young university students at UCLA (on average 28 years old) has a better performance in their speech production than the second group of adult students (on average 65 year old); not only because the age difference, but also because of the first group learning French as a main subject in their university syllabus, while the second one is learning French mainly for pleasure and travel purpose.

The second hypothesis is that the real-time visualization during the prosodic training with WinPitch helps the students in improving their quality and 'natural sounding' of their speech productions in French.

\section{Corpus}

The corpus includes recordings from a model French speaker and the students from the two groups, all reading a short declarative text "Dimanche en famille", a text coming from a short story written by P. Léon.

In this paper, only one sample sentence out of the whole corpus is analyzed: Elle aimerait bien une petite friture de poissons. "She would like to eat some deep-fried fish." Results from two male speakers of the first group and two female speakers of the second group are shown, see the Figs below.

\section{WinPitch and L2 teaching}

In this study we work with WinPitch LTL, a program developed for language teaching and learning by Philippe Martin, and WinPitch Pro. WinPitch LTL was first presented to potential users in Martin and Germain (2000), and is innovative in its real-time visualization. Designed as a traditional language lab with two tracks, the students first listen to the model speech and then try to reproduce it. The instructor can directly correct errors of the student's repetition (suprasegmental and segmental) or add comments for the next class. He can also manipulate the F0 curve and use different colorings to highlight, e.g., a rising/falling intonation or a final intonation.

\section{WinPitch screenshots of student's oral productions}

In this section we will consider WinPitch screenshots from the students of the two groups. First the comparison of the sentence production (two recordings of each speaker) without training and then after training, during the final recordings. For the results in some cases, I accepted almost correct oral production as good, see the tables below. 

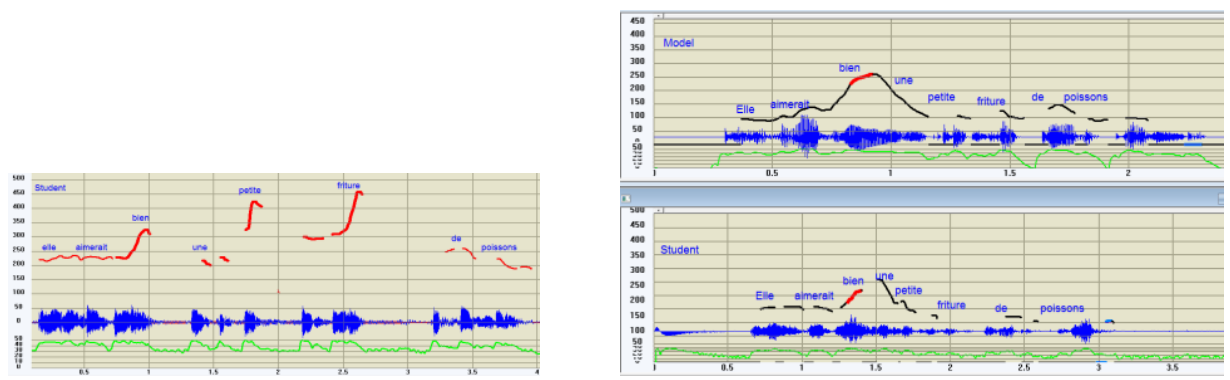

Figure 1.
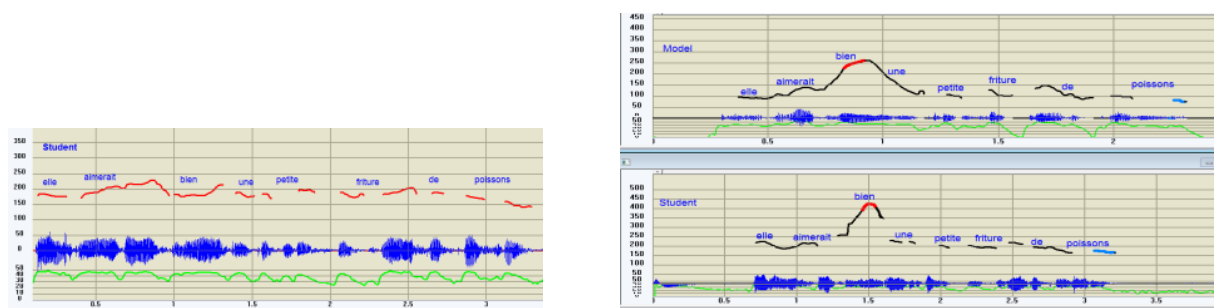

Figure 2.
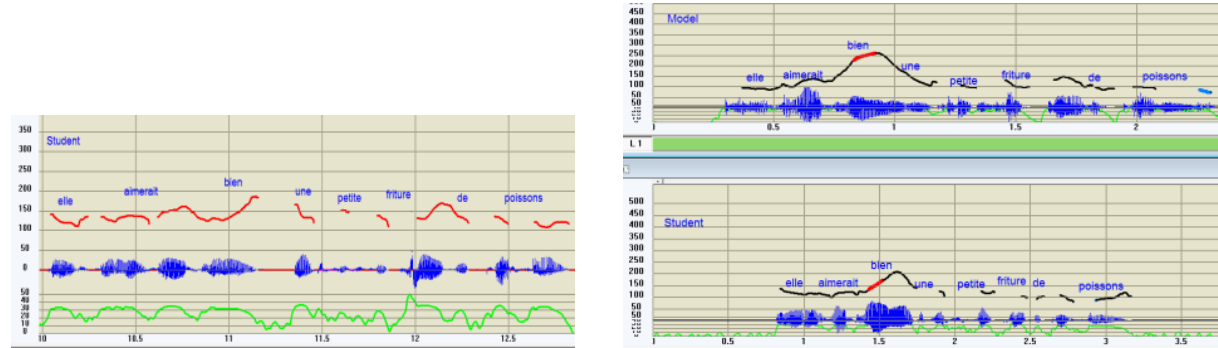

Figure 3.
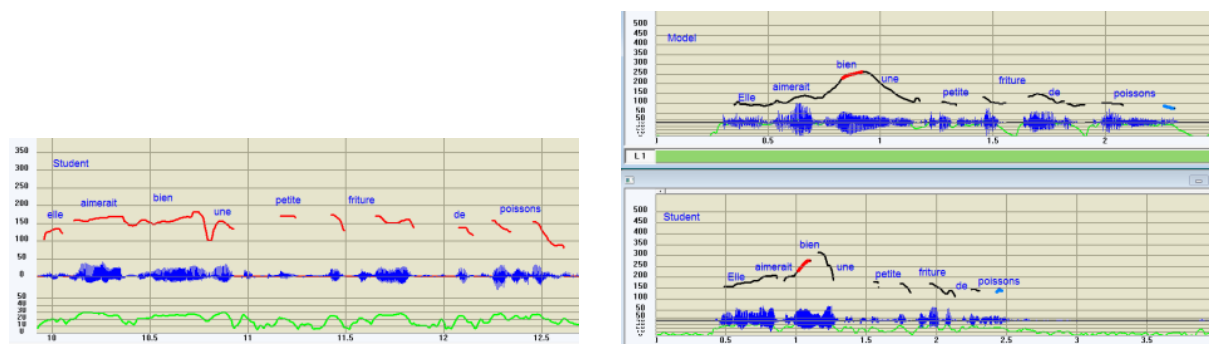

Figure 4.

Figures 1-4. Figure 1: Group 2 student 1, WP Pro first recording (left) and WP LTL final recording (right). Figure 2: Group 2 student 2, WP Pro first recording (left) and WP LTL final recording (right). Figure 3: Group 1 student 1, WP Pro first recording (left) and WP LTL final recording (right). Figure 4: Group 1 student 2, WP Pro first recording (left) and WP LTL final recording (right). 
Table 1.

\begin{tabular}{|l|l|l|l|l|}
\hline \hline $\begin{array}{l}\text { Elle aimerait bien une } \\
\text { petite friture de poissons }\end{array}$ & First rec. & Final rec. & First rec. & Final rec. \\
\hline Prosodic words & - & - & + & + \\
\hline Declarative (C0d) & + & + & + & + \\
\hline Prominence "bien" & + & + & + & + \\
\hline Speech fluency\&v.linking & - & - & + & + \\
\hline
\end{tabular}

Table 2 .

\begin{tabular}{|l|l|l|l|l|}
\hline \hline \multirow{2}{*}{$\begin{array}{l}\text { llle aimerait bien une petite } \\
\text { friture de poissons }\end{array}$} & First rec. & Final rec. & First rec. & Final rec. \\
\cline { 2 - 5 } & Sp.1gr.1 & Sp.1gr.1 & Sp.2gr.1 & Sp.2gr.1 \\
\hline Prosodic words & - & + & - & + \\
\hline Declarative (C0d) & $+(!)$ & + & + & + \\
\hline Prominence "bien" & + & + & + & + \\
\hline Speech fluency\&v.linking & - & + & - & $-/+$ \\
\hline
\end{tabular}

\section{Conclusions}

The results of the presented sample sentence suggest a clear improvement in the speech production for the students in both groups after a training with WinPitch LTL. In a next step, we will continue analyze the full corpus, read by other speakers from the two groups, to confirm the hypothesis that the language proficiency depends on the pursued purpose, the wish to sound more natural, to be aware of the foreign language intonation while speaking.

\section{References}

Abry, D., Chalaron, M-L. 2009. Les 500 Exercices de phonétique A1/A2. Hachette.

Germain, A., Martin, P. 2000. Présentation d'un logiciel de visualisation pour l'apprentissage de l'oral en langue seconde. www.alsic.org, 3, No 1, 61-76.

Gumbretière, E. 1994. Phonétique et enseignement de l'oral. Paris, Didier-Hatier.

James, E. 1976. The acquisition of prosodic features of speech using a speech visualizer. IRAL 14 (3):227-243.

Kamoun, Ch., Ripaud, D. 2016. Phonétique essentielle du français. 100\% FLE, Paris, Didier.

Lauret, B. 2007. Enseigner la prononciation du français: questions et outils. Paris, Hachette.

Martin, Ph. 1982. Utilisation d'un visualiseur de mélodie en vue d'une didactique. Options nouvelles en didactique du français langue étrangère. 181-186. Paris, Didier.

Martin, Ph. 1975. Analyse phonologique de la phrase française. Vol. 146, 35-68. Linguistics.

WinPitch LTL, 2015. www.winpitch.com. 